\title{
A parsimonious AUC-based biokinetic method to estimate relative bioavailable zinc to abalone Haliotis diversicolor supertexta
}

\author{
Chung-Min Liao*, Bo-Ching Chen, Jeng-Wei Tsai, \\ Jein-Wen Chen, Min-Pei Ling, Yun-Hua Chou
}

Department of Bioenvironmental Systems Engineering, National Taiwan University, Taipei 10617, Taiwan, ROC

Received 16 May 2003; received in revised form 1 August 2003; accepted 4 August 2003

\begin{abstract}
We developed a mechanistic model based on the pharmacological area-under-curve (AUC) concept associated with a biokinetic rate model to predict relative bioavailable zinc $(\mathrm{Zn})$ to abalone Haliotis diversicolor supertexta. We conducted a laboratory 14-day exposure experiment to obtain biokinetic parameters for soft tissue and shell of abalone and their food source, red alga Gracilaria tenuistipitata var. liui. The physiological parameters in terms of growth rate constants for abalone and algae were derived from literature. The present AUC-based model demonstrates that depuration rate constants and growth rate constants of abalone and algae are the critical parameters in predicting relative bioavailable $\mathrm{Zn}$ to abalone. During uptake phase of the exposure experiment, estimated relative bioavailable $\mathrm{Zn}$ to soft tissue and shell of $H$. diversicolor supertexta were $71.04 \pm 9.71 \%$ (mean \pm standard deviation) and $68.44 \pm 8.29 \%$, respectively. Sensitivity analysis indicates that relative bioavailable $\mathrm{Zn}$ to abalone is greatly affected by growth rate and depuration rate constants of abalone and is less dependent on algae growth rate. We also applied a Monte Carlo approach to estimate the impact of parameter uncertainty on relative bioavailable $\mathrm{Zn}$ predictions. Our results suggest that the probabilistic approach allows a range of possible outcomes and their likelihood; it better informs both aquacultural risk assessors and risk managers. Our study suggests that we have to take into account both biokinetic and physiological processes in predicting the relative bioavailable metals to aquatic animals.
\end{abstract}

(C) 2004 Elsevier B.V. All rights reserved.

Keywords: Abalone; Algae; Area-under-curve; Bioavailability; Zinc

* Corresponding author. Tel.: +886-2-2363-4512; fax: +886-2-2362-6433.

E-mail address: cmliao@ccms.ntu.edu.tw (C.-M. Liao). 


\section{Introduction}

The bioavailable and trophic transfer of metals in aquatic food chains has received considerable attention in recent years in an effort to better understand the geochemical cycling of metals and the nutritional and toxicological effects of metals in aquatic organisms (Wang et al., 1999; Lee et al., 2000; Reinfelder and Fisher, 2001). Assessment of bioavailable metals to aquacultural animals may help to determine if the metal levels are sufficiently high to be bioavailable and toxic, therefore requiring pond cleanup criteria. A mechanistic understanding of bioavailable metals to aquacultural species, however, is limited for most of these studies. The routes and rates of metal uptake are relatively unknown for most metals and most aquacultural species.

It is appropriate to develop a new approach to address bioavailable metals to aquacultural species by considering all processes responsible for metal bioaccumulation and the variations likely to be encountered in the field. We combine kinetic and pharmacological modeling approaches to develop a mechanistic model to predict bioavailable metals to aquacultural species. With this model, those physiological processes controlling bioavailable metals to aquacultural species can be identified and estimated under varying environmental conditions that are likely encountered by the species in the field.

The proposed mechanistic model, which incorporates all potential sources of metal uptake, appears to be the appropriate approach for understanding bioavailable metals to species and metal bioaccumulation in species, but its application has only recently been exploited. Using laboratory measurements of several key parameters, this proposed model can be readily used to quantify the relative importance of different pathways in bioavailable metals to aquacultural species.

In ecotoxicology, bioavailable fraction of a substance can be broadly defined as the portion of a chemical in the environment that is available for biological action such as uptake by an organism or that can cause a biological response (van Straalen, 1996). Thus, the bioavailable fraction of a substance is that part of the total concentration which can actually be taken by aquatic animals. The bioavailable metals to aquatic animals are determined by a complex interaction of biological and ecological factors such as habitat, feeding behavior, and digestion mechanisms. It is closely linked to the pharmacological definition of bioavailable fraction of a substance, which is the portion of a chemical in food that is available for uptake by an organism, e.g., reaches the systemic circulation of the organism (O'connell et al., 2000; Pelkonen et al., 2001).

In pharmacology, bioavailable fraction of a substance is most often calculated from the ratio of the absorbed dose representing by the areas under concentration-time curves (AUCs) of a toxicant to the ingested dose (Horsberg et al., 1996; McCloskey et al., 1998; Roberts et al., 2002). Martinsen et al. (1993a,b), and McCloskey et al. (1998) have used the pharmacological method to estimate the bioavailability of florfenicol and $\mathrm{CH}_{3} \mathrm{Hg}$ from food in Atlantic salmon (Salmo salar) and channel catfish (Ictalurus punctatus), respectively.

In the biokinetic scheme, the conventional approach to estimate bioavailable metals to organisms is by quantifying a mathematical equation that relates metal content in the organisms with ambient dissolved metal concentration to produce the metal bioaccumu- 
lation factor (BAF) (Wang and Fisher, 1997; Reinfelder et al., 1998; Yan and Wang, 2002). Differences in BAF reflect differential relative bioavailable metals to organisms. Using BAF approach, bioavailable zinc $(\mathrm{Zn})$ has been reported to between $70 \%$ and $80 \%$ to marine copepods, between 55\% and 65\% to bivalves (Crassostrea virginica, Mercenaria mercenaria, Marcoma balthica), and between $25 \%$ and $35 \%$ to marine mussel (Mytilus edulis) in which the elimination rate constants ranged from 0.01 to 0.1 day $^{-1}$ (Reinfelder et al., 1998; Lee et al., 2000). McCloskey et al. (1998) pointed out that bioavailability estimates using the pharmacological methods were much lower than estimates using BAF approaches, suggesting that BAF approaches may overestimate the true bioavailability of toxicants in fish.

In this study, we estimated bioavailable dietborne $\mathrm{Zn}$ to abalone Haliotis diversicolor supertexta by quantifying the trophic transfer of $\mathrm{Zn}$ in abalone from red alga Gracilaria tenuistipitata var. liui. H. diversicolor supertexta is the most abundant abalone species in Taiwan. The red alga G. tenuistipitata var. liui is the major forage for culturing the abalone. These two species are commercially important for fisheries and aquaculture in Taiwan. $H$. diversicolor supertexta is also appreciated for its delicacy and high market value; the aquaculture of $H$. diversicolor supertexta thus is a promising business. The coastal regions of Taiwan where abalone and algae farms are located, however, are subjected to polluted discharges from rivers. Zinc is available to abalone from both the dissolved phase and the diet. If waterborne $\mathrm{Zn}$ levels are elevated, however, toxicity can occur and have severe effects on the health of abalone, which will reduce the market price and cause closure of abalone farms. Previous investigations indicated that maximum $\mathrm{Zn}$ concentrations in contaminated aquacultural water are reported to be ranged from 60 to $300 \mu \mathrm{g}^{-1}$ in different areas of Taiwan (Lin and Liao, 1999).

The main purpose of the present study was to combine both first-order biokinetic and AUC-based models to estimate bioavailable $\mathrm{Zn}$ to $H$. diversicolor supertexta. The methods used in the present study will be distinct as the BAF approach. We estimated the abalone assimilation efficiency of $\mathrm{Zn}$ from ingested algae. We determined bioavailable $\mathrm{Zn}$ to soft tissue and shell of $H$. diversicolor supertexta and examined the controlling mechanisms. A kinetic rate equation was employed to determine assimilation efficiency and depuration rate constants of abalone and algae from an exposure experiment. This AUC-based biokinetic approach has been used rarely in ecotoxicology and has never been used for bioavailable $\mathrm{Zn}$ to $H$. diversicolor supertexta. There are uncertainties in the measurement of physiological and biokinetic parameters that are used to predict bioavailable $\mathrm{Zn}$ as conducted in this study. Thus, we performed the sensitivity and uncertainty analyses for the proposed bioavailable $\mathrm{Zn}$ prediction model.

\section{Materials and methods}

\subsection{Experimental section}

Live abalone $H$. diversicolor supertexta, and the alga $G$. tenuistipitata var. liui were collected from Toucheng located in northern Taiwan for the laboratory exposure experiments because this place was the most $\mathrm{Zn}$-contaminated area. Abalone with a shell length 
of $3.4 \pm 0.8 \mathrm{~cm}$ were selected for the experiments. The algal samples selected were mature, whole and healthy. A total of 180 abalone was transferred into four aquatic tanks of approximately 54-1 volume, containing 501 of artificial seawater. In order to imitate the environment of the abalone farms, the abalone were held in baskets. Each tank contained 10 baskets. Four abalone per basket were used for analysis.

To assure that at least four abalone would be alive at the end of the experiment, we put one extra abalone in each basket. Dissolved oxygen was maintained at close to saturation by aeration throughout the experiment. The temperature was maintained at $24 \pm 2.3{ }^{\circ} \mathrm{C}$ under constant illumination (Yang and Ting, 1986, 1994). The salinity was maintained at $35 \pm 1.5$. The $\mathrm{pH}$ remained fairly constant during the assays $(7.54 \pm 1.07)$. Abalone were fed daily with $G$. tenuistipitata var. liui. The abalone and algae were acclimatized for 2 weeks before they were exposed to $\mathrm{Zn}$.

In two tanks, $\mathrm{Zn}\left(\mathrm{ZnCl}_{2}\right)$ was added to the seawater; in one tank, the abalone were fed with algae (water/food-exposed), and in the other tank, the abalone were kept without food (water-exposed). The $\mathrm{Zn}$ contamination level was determined by a preliminary test exposing abalone to different $\mathrm{Zn}$ concentrations of $0.25,0.5,1,2$, 4, and $6 \mathrm{mg} \mathrm{l}^{-1}$. The median lethal tolerance $\left(\mathrm{LT}_{50}\right)$ of abalone at $\leq 1 \mathrm{mg} \mathrm{l}^{-1} \mathrm{Zn}$ was longer than 3 weeks. Thus, the organisms were exposed to $1 \mathrm{mg} \mathrm{l}^{-1} \mathrm{Zn}$ for 7 days. The algae and the abalone were reared in the contaminated environment for 7-day uptake, then transferred to clean seawater and reared for 7 days of depuration. To examine if starvation affects $\mathrm{Zn}$ depuration in abalone, the same procedure with abalone and algae was followed over 14 days using the other two tanks, but without $\mathrm{Zn}$ in the sea water.

Abalone, algae and water samples were collected at days $0,1,2,4$, and 7 , starting from the day that those organisms were exposed to the contaminated seawater and from the day the organisms were transferred to clean seawater. Every time we took one basket along with $500 \mathrm{ml}$ water out of each tank. From this basket, four pieces of algae and four abalone were collected. Because preliminary observation showed that $H$. diversicolor supertexta only feeds at night and has an empty gut in the evening, we collected the abalone at night to make sure the contents of gut would not influence the results. The experiments in the four tanks, described above, were repeated again. The water samples were fixed with $5 \mathrm{ml} 1 \mathrm{~N} \mathrm{HNO}_{3}$, and the samples of abalone were stored in the dark at $-20{ }^{\circ} \mathrm{C}$ until they were analyzed.

\subsection{Metal analysis}

The algae and dissected abalone including soft tissue and shell were freeze-dried overnight, and then grounded into a fine powder in a grinder (Tai-Hsiang S36-89, Taiwan). The 500-mg portions of the ground samples were digested in $10 \mathrm{ml}$ of $65 \%$ concentrated $\mathrm{HNO}_{3}(\mathrm{v} / \mathrm{v})$ overnight at room temperature. The resulting solution was evaporated and redissolved in $0.1 \mathrm{~N} \mathrm{HCl}$. Zinc analysis was carried out by atomic absorption spectrophotometry using a Perkin-Elmer model 5000 atomic absorption flame spectrophotometer (Perkins-Elmer, Shelton, CT, USA) equipped with a graphite furnace. The detection limit was $5 \mu \mathrm{g} \mathrm{Zn/l} \mathrm{water} \mathrm{and} 0.5 \mu \mathrm{g} \mathrm{Zn/g} \mathrm{tissue.} \mathrm{External} \mathrm{quality} \mathrm{control} \mathrm{was} \mathrm{achieved} \mathrm{by}$ digesting and analyzing identical amounts of rehydrated ( $90 \%$ water) standard reference materials (DORM-2, Dogfish Liver-2-organic matrix, provided by the NRC-CNRC, National Research Council, Canada). Recovery rate was $97 \pm 1.7 \%$. 


\subsection{Data analysis}

Growth rates were calculated by fitting abalone shell length data obtained from Yang and Ting $(1986,1994)$ to an exponential model (ln shell length $(L)=a+g t$, where $a$ is a constant, $g$ is the growth rate (day ${ }^{-1}$ ), and $t$ is the time in days). Depuration rate constants $\left(k_{\mathrm{d}}\right)$ were determined by fitting concentration $C$ to a first-order decay curve (ln $C=c+\left(k_{\mathrm{d}}+g\right) t$ where $c$ is a constant and $t$ is the time in days). Depuration half-lives $\left(t_{1 / 2}\right)$ were calculated as $\ln 2 /\left(k_{\mathrm{d}}+g\right)$.

The method to determine assimilation efficiency was by fitting concentration data to the integrated form of the kinetic equation for constant water and time-dependent dietary exposure, using iterative nonlinear regression (Reinfelder et al., 1998),

$$
C_{\mathrm{m}}(t)=C_{\mathrm{m}}(0) \mathrm{e}^{-\left(k_{\mathrm{d}}+g\right) t}+\frac{\left(k_{\mathrm{u}} C_{\mathrm{w}}\right)+\left(\alpha f C_{\mathrm{a}}(t)\right)}{k_{\mathrm{d}}+g}\left(1-\mathrm{e}^{-\left(k_{\mathrm{d}}+g\right) t}\right),
$$

where $\alpha$ is the assimilation efficiency of abalone, $f$ is the abalone grazing rate $(0.25 \pm 0.05$ $\mathrm{g} \mathrm{g}^{-1}$ day $^{-1}$ Chen and Lee, 1999), $C_{\mathrm{m}}(t)$ is the time-dependent $\mathrm{Zn}$ concentration in abalone $\left(\mu \mathrm{g} \mathrm{g}^{-1}\right), C_{\mathrm{w}}$ is the dissolved $\mathrm{Zn}$ concentration in water $\left(\mu \mathrm{g} \mathrm{ml}^{-1}\right), C_{\mathrm{a}}(t)$ is the time-dependent $\mathrm{Zn}$ concentration in algae $\left(\mu \mathrm{g} \mathrm{g}^{-1}\right), t$ is the time (day), and $k_{\mathrm{u}}$ is the abalone uptake rate of $\mathrm{Zn}\left(\mathrm{ml} \mathrm{g}^{-1}\right.$ day $\left.^{-1}\right)$ and can be obtained by fitting concentration data to the kinetic equation (i.e., the first-order one-compartment uptake-depuration model) for constant water exposure, using nonlinear iterative regression,

$$
C_{\mathrm{m}}(t)=C_{\mathrm{m}}(0) \mathrm{e}^{-\left(k_{\mathrm{d}}+g\right) t}+\mathrm{BCFC}_{\mathrm{w}}\left(1-\mathrm{e}^{-\left(k_{\mathrm{d}}+g\right) t}\right),
$$

where $\mathrm{BCF}$ is the bioconcentration factor of abalone for $\mathrm{Zn}$ and can also be expressed as $\mathrm{BCF}=k_{\mathrm{u}} /\left(k_{\mathrm{d}}+g\right)$. Biomagnification factor (BMF) was calculated from the equation $\mathrm{BMF}=\alpha f\left(k_{\mathrm{d}}+g\right)$. For food source of abalone, the red algae G. tenuistipitata var. liui, the uptake rate constant $\left(k_{1 \mathrm{a}}\right)$ and depuration rate constant $\left(k_{2 \mathrm{a}}\right)$ can also be calculated by fitting the concentration data to the kinetic equation for constant water exposure, using nonlinear iterative regression,

$$
C_{\mathrm{a}}(t)=C_{\mathrm{a}}(0) \mathrm{e}^{-\left(k_{2 \mathrm{a}}+g_{\mathrm{a}}\right) t}+\frac{k_{1 \mathrm{a}}}{\left(k_{2 \mathrm{a}}+g_{\mathrm{a}}\right)} C_{\mathrm{w}}\left(1-\mathrm{e}^{-\left(k_{2 \mathrm{a}}+g_{\mathrm{a}}\right) t}\right),
$$

where $g_{\mathrm{a}}$ is the G. tenuistipitata var. liui growth rate $\left(0.038 \pm 0.013\right.$ day $^{-1}$ Lee et al., 1999). Bioconcentration factor of algae $\left(\mathrm{BCF}_{\mathrm{a}}\right)$ can be calculated by the equation $\mathrm{BCF}=k_{1 \mathrm{a}} /\left(k_{2 \mathrm{a}}+g_{\mathrm{a}}\right)$.

We employed the nonlinear option of the Statistica ${ }^{\circledR}$ software (StatSoft, Tulsa, OK, USA) to perform all curve fittings. The Statistica ${ }^{\circledR}$ was also used to calculate the coefficient of determination $\left(r^{2}\right)$ and to perform other statistical analyses (analysis of variance and Student's $t$-test). Statistical significance was determined if $p$ values were less than 0.05 . 


\subsection{Modeling bioavailable Zn to abalone}

The amount of $\mathrm{Zn}$ absorbed through abalone (bioabailable $\mathrm{Zn}$ ) can be described in absolute and relative terms. Absolute bioavailability $\left(F_{\mathrm{a}}\right)$, also referred to as the absorption fraction, is given by: $F_{\mathrm{a}}=$ absorbed dose/ingested dose (Schroder et al., 2003). For a consumer-resource system in the trophic transfer processes between abalone and algae, the relative bioavailability, $F$, is used and can be expressed as the ratio of the $F_{\mathrm{a}}$ of $\mathrm{Zn}$ present in consumer (abalone) to the $F_{\mathrm{a}}$ of $\mathrm{Zn}$ in resource (algae), that is (Schroder et al., 2003),

$$
F=F_{\text {a }}(\text { abalone }) / F_{\text {a }}(\text { algae }) .
$$

Bourne (1995) and de Vries (1996) suggested that in pharmacokinetic modeling, the AUC is commonly applied to estimate the total amount of substance eliminated from the whole body of organisms over a certain time period. Analogously, over a certain time period, the total amount of absorbed dose in the target tissue is equal to the amount of toxic compound that has been removed from the target tissue, i.e., AUC can be a surrogate measurement for the absorbed dose.

The concept of the relative bioavailability in this present research could be restated as follows: Relative bioavailable $\mathrm{Zn}$ to abalone is determined by assessing the proportion of $\mathrm{Zn}$ that can be taken up by abalone from their food source, the red algae G. tenuistipitata var. liui. Therefore, the time-dependent relative bioavailable $\mathrm{Zn}$ to abalone $(F(t))$ is calculated according to Eq. (4) as,

$$
F \equiv \frac{\left[\mathrm{AUC} / D_{\mathrm{n}}\right]_{\text {abalone }}}{\left[\mathrm{AUC} / D_{\mathrm{n}}\right]_{\text {algae }}} \Rightarrow F(t)=\frac{\mathrm{AUC}_{\mathrm{m}}}{\mathrm{AUC}_{\mathrm{a}}} \times \frac{D_{\mathrm{n}, \mathrm{a}}(t)}{D_{\mathrm{n}, \mathrm{m}}(t)}=\frac{\int_{0}^{t} C_{\mathrm{m}}(t) \mathrm{d} t}{\int_{0}^{t} C_{\mathrm{a}}(t) \mathrm{d} t} \times \frac{D_{\mathrm{n}, \mathrm{a}}(t)}{D_{\mathrm{n}, \mathrm{m}}(t)},
$$

where $\mathrm{AUC}_{\mathrm{m}}$ and $\mathrm{AUC}_{\mathrm{a}}$ are the areas under the whole-body burden of $\mathrm{Zn}$ concentrations in abalone and in algae versus time curves, respectively ( $\mu \mathrm{g} \mathrm{g}^{-1}$ day), and $D_{\mathrm{n}, \mathrm{m}}$ and $D_{\mathrm{n}, \mathrm{a}}$ represent the doses normalized to the body mass of abalone and algae, respectively ( $\mu \mathrm{g}$ $\mathrm{g}^{-1}$ ) and can be seen as the whole-body burdens of $\mathrm{Zn}$ in abalone (i.e., $\left.C_{\mathrm{m}}(t)\right)$ and in algae (i.e., $\left.C_{\mathrm{a}}(t)\right)$, respectively.

The mean residence time (MRT) of $\mathrm{Zn}$ in abalone is calculated by dividing the first moment of the whole-body Zn burden versus time profile by the AUC (Bourne, 1995),

$$
\operatorname{MRT}=\frac{\int_{0}^{t} t C_{\mathrm{m}}(t) \mathrm{d} t}{\int_{0}^{t} C_{\mathrm{m}}(t) \mathrm{d} t} .
$$

We consider constant dietary exposure and $C_{\mathrm{m}}(0)=0$ in Eq. (1), $\mathrm{AUC}_{\mathrm{m}}$ in Eq. (5) has the form as,

$$
\mathrm{AUC}_{\mathrm{m}}=\int_{0}^{t} C_{\mathrm{m}}(t) \mathrm{d} t=\left[\frac{\mathrm{BCFC}_{\mathrm{w}}+\mathrm{BMFC}_{\mathrm{a}}}{\left(k_{\mathrm{d}}+g\right)}\right]\left(\left(k_{\mathrm{d}}+g\right) t+\mathrm{e}^{-\left(k_{\mathrm{d}}+g\right) t}-1\right) .
$$


Similarly, $\mathrm{AUC}_{\mathrm{a}}$ has the form as,

$$
\mathrm{AUC}_{\mathrm{a}}=\int_{0}^{t} C_{\mathrm{a}}(t) \mathrm{d} t=\frac{\mathrm{BCF}_{\mathrm{a}}}{\left(k_{2 \mathrm{a}}+g_{\mathrm{a}}\right)} C_{\mathrm{w}}\left(\left(k_{2 \mathrm{a}}+g_{\mathrm{a}}\right) t+\mathrm{e}^{-\left(k_{2 \mathrm{a}}+g_{\mathrm{a}}\right) t}-1\right) .
$$

By substituting Eqs. (2), (3), (7) and (8) into Eq. (5), the mathematical expression of relative bioavailable $\mathrm{Zn}$ to abalone subject to constant water and dietary exposure has a following explicit form in terms of biokinetic and physiological parameters as,

$$
\begin{aligned}
F(t)= & {\left[\frac{\left(k_{\mathrm{d}}+g\right) t+\mathrm{e}^{-\left(k_{\mathrm{d}}+g\right) t}-1}{\left(k_{2 \mathrm{a}}+g_{\mathrm{a}}\right) t+\mathrm{e}^{-\left(k_{2 \mathrm{a}}+g_{\mathrm{a}}\right) t}-1}\right]\left[\frac{\left(k_{2 \mathrm{a}}+g_{\mathrm{a}}\right)\left(1-\mathrm{e}^{-\left(k_{2 \mathrm{a}}+g_{\mathrm{a}}\right) t}\right)}{\left(k_{\mathrm{d}}+g\right)\left(1-\mathrm{e}^{-\left(k_{\mathrm{d}}+g\right) t}\right)}\right], } \\
= & \frac{\frac{t}{\left(1-\mathrm{e}^{-\left(k_{\mathrm{d}}+g\right) t}\right)}-\frac{1}{\left(k_{\mathrm{d}}+g\right)}}{\left(1-\mathrm{e}^{-\left(k_{2 \mathrm{a}}+g_{\mathrm{a}}\right) t}\right)}-\frac{1}{\left(k_{2 \mathrm{a}}+g_{\mathrm{a}}\right)}
\end{aligned}
$$

Eq. (9) reveals that four parameters, abalone depuration rate constant for $\mathrm{Zn}\left(k_{\mathrm{d}}\right)$, algae depuration rate constant for $\mathrm{Zn}\left(k_{2 \mathrm{a}}\right)$, algae growth rate $\left(g_{\mathrm{a}}\right)$, and abalone growth rate $(g)$, are needed to predict the relative bioavailable $\mathrm{Zn}$ to abalone due to trophic transfer and water exposure.

\section{Results and discussion}

\subsection{Physiological and biokinetic parameters}

The best fit of growth rate model for shell length of 2-3.5 and 4-5 cm of abalone H. diversicolor supertexta shows relatively high $r^{2}$ values (Fig. 1 and Table 1). The 14-day water exposure experiment of $\mathrm{Zn}$ in soft tissue and shell of $H$. diversicolor supertexta and algae $G$. tenuistipitata var. liui had significant correlated nonlinear regression profiles $\left(p<0.05, r^{2}=0.68-0.99\right)$ resulting from the best fit of the firstorder one-compartment uptake-depuration model (Fig. 2). Table 2 summarizes the experimentally determined bioaccumulation parameters for $\mathrm{Zn}$ calculated from $H$. diversicolor supertexta and $G$. tenuistipitata var. liui exposure data.

The assimilation efficiency for $\mathrm{Zn}$ in $H$. diversicolor supertexta was in the range of 20 49\% (Table 2). Wang and Fisher (1997), Reinfelder et al. (1998) and Lee et al. (2000) reported that the average assimilation efficiencies for $\mathrm{Zn}$ in marine copepods and mussels ranged from $32 \%$ to $57 \%$. The calculated biological retention half-lives for soft tissue and shell of abalone were about 53 and 16 days, respectively (Table 2), indicating that Zn can be very efficiently retained in soft tissue than that in shell.

\subsection{Relative bioavailable $\mathrm{Zn}$ to abalone}

With known growth rate constants and depuration rate constants for abalone and algae, Eq. (9) was then used to calculate the relative bioavailable $\mathrm{Zn}$ to $H$. diversicolor supertexta, in that trophic transfer and water exposure account for the apparent accumu- 


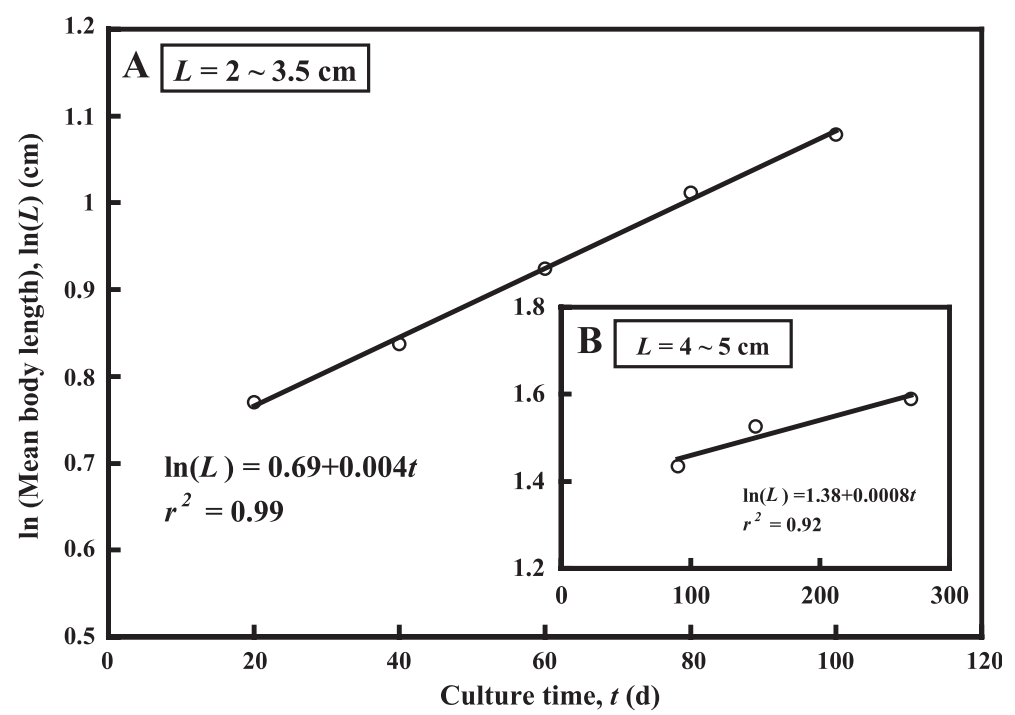

Fig. 1. Optimal fits of growth rate model for shell length $(L)$ of abalone $H$. diversicolor supertexta at (A) $L=2-$ $3.5 \mathrm{~cm}$ and (B) $L=4-5 \mathrm{~cm}$ in which open circles denote data points obtained from Yang and Ting $(1986,1994)$ and solid lines represent growth model fitting.

lation of $\mathrm{Zn}$. The calculated relative bioavailable $\mathrm{Zn}$ to abalone during uptake phase in the exposure experiment is illustrated in Fig. 3. The relative bioavailable $\mathrm{Zn}$ to abalone decreased rapidly in the first 2 days then attained a steady-state by the end of the uptake phase. In the 7-day uptake experiment, the time-dependent relative bioavailable $\mathrm{Zn}$ to soft tissue and shell of $H$. diversicolor supertexta decreased from around $89 \%$ in the first day to around $60 \%$ in day 7 (Fig. 3A). Estimated average relative bioavailable $\mathrm{Zn}$ to soft tissue and shell of $H$. diversicolor supertexta were $71.04 \pm 9.71 \%$ and $68.44 \pm 8.29 \%$, respectively, during uptake phase (Fig. 3B).

Reinfelder et al. (1998) reported that relative bioavailable $\mathrm{Zn}$ to marine copepods and to bivalves (C. virginica, $M$. mercenaria, $M$. balthica) ranged between $70-80 \%$ and $55-$ $65 \%$, respectively, when depuration rate constants varied between 0.01 and 0.1 day $^{-1}$. Therefore, using $H$. diversicolor supertexta collected from coastal water-cultured abalone farms in Taiwan as an example, these estimated relative bioavailable $\mathrm{Zn}$ are remarkably comparable to the field-measured values (55-80\%), suggesting that the parameters identified in the AUC-based model can account for relative bioavailable $\mathrm{Zn}$ to abalone.

Table 1

Growth rate constants (mean \pm 1 S.E.) for $H$. diversicolor supertexta ${ }^{\mathrm{a}}$

\begin{tabular}{ll}
\hline Shell length $(\mathrm{cm})$ & Growth rate $\left(10^{-3} \text { day }^{-1}\right)^{\mathrm{b}}$ \\
\hline $2-3.5$ & $4.0 \pm 0.12\left(r^{2}=0.99\right)$ \\
$4-5$ & $0.8 \pm 0.23\left(r^{2}=0.92\right)$ \\
\hline
\end{tabular}

${ }^{\text {a }}$ Observation data obtained fromYang and Ting $(1986,1994)$.

${ }^{\mathrm{b}}$ Growth rates calculated using the equation $\ln$ lenght $=a+g$ (time) (day), where $g$ is the growth rate and $r^{2}$ is the coefficient of determination. 

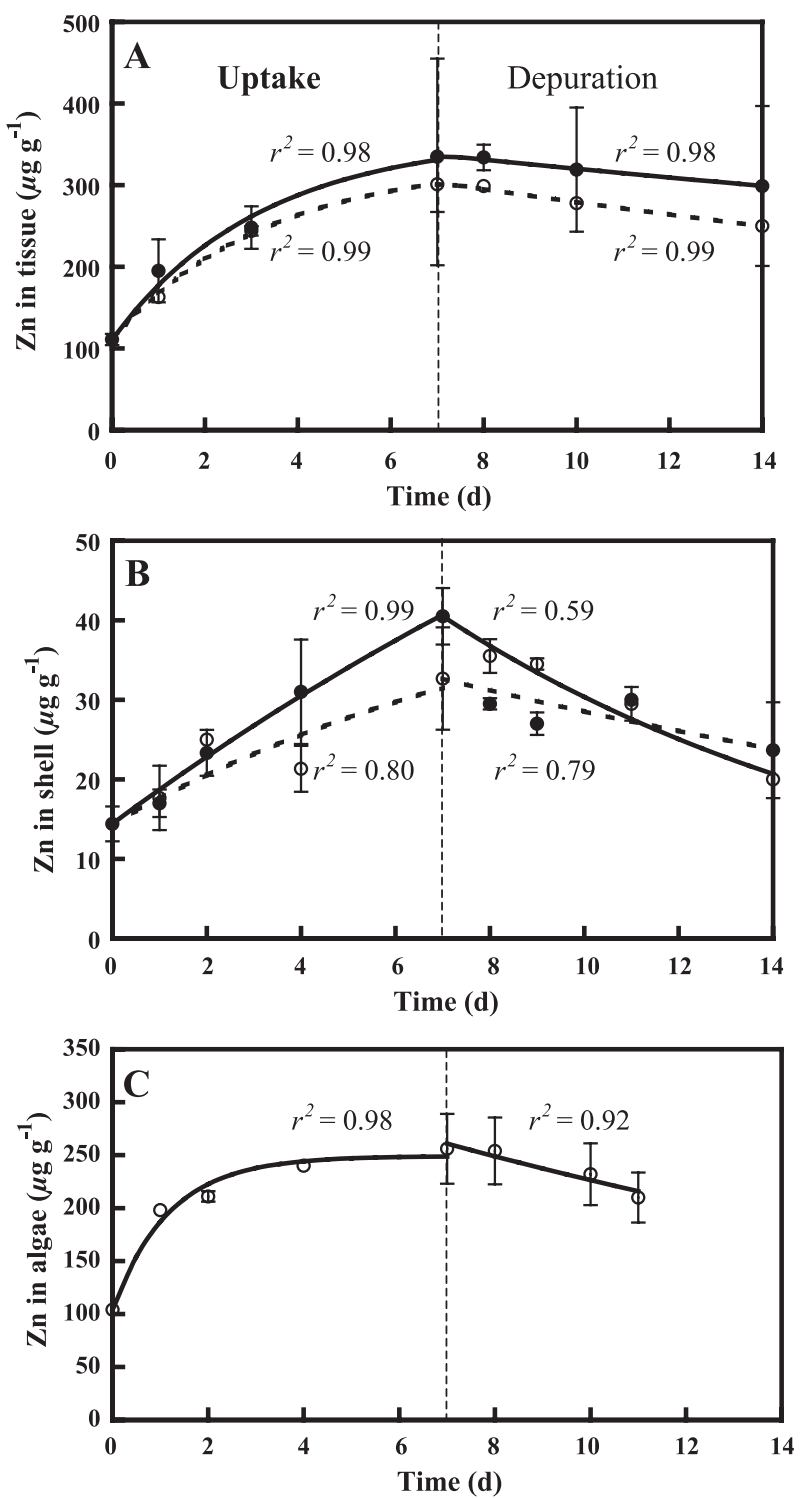

Fig. 2. Optimal fits of laboratory 14-day exposure experiment of uptake and depuration of Zn by (A) soft tissue and (B) shell of $H$. diversicolor supertexta during 7-day exposure and then 7-day depuration period. The measurements are shown with symbols (- fed with algae; $\bigcirc$ : kept without algae); and model fittings are shown in lines (-: fed with algae; $\cdots:$ kept without algae) and (C) uptake/depuration of Zn by red alga G. tenuistipitata var. liui where measurements are shown with symbols and the model fitting is shown in solid line. Error bars show one standard deviation from the mean. 
Table 2

Physiological and bioaccumulation parameters (mean \pm 1 S.E.) for $\mathrm{Zn}$ calculated from abalone H. diversicolor supertexta and algae G. tenuistipitata var. liui exposure experiment

\begin{tabular}{|c|c|}
\hline Parameters & Values \\
\hline \multicolumn{2}{|l|}{ Soft tissue of $H$. diversicolor supertexta } \\
\hline Assimilation efficiency, $\alpha(\%)^{\mathrm{a}}$ & $34.57 \pm 14.60(0.199-0.492)$ \\
\hline \multirow[t]{2}{*}{ Depuration rate constant, $k_{\mathrm{d}}\left(\mathrm{day}^{-1}\right)^{\mathrm{b}}$} & $0.013 \pm 0.0015$ (with algae) \\
\hline & $0.024 \pm 0.002$ (without algae) \\
\hline Depuration half-life, $t_{1 / 2}(\mathrm{~d})^{\mathrm{c}}$ & 53.31 \\
\hline Uptake rate constant, $k_{\mathrm{u}}\left(\mathrm{ml} \mathrm{g}^{-1} \text { day }^{-1}\right)^{\mathrm{a}}$ & $99.13 \pm 7.48$ \\
\hline $\mathrm{BMF}^{\mathrm{a}}$ & $4.95 \pm 2.05$ \\
\hline $\mathrm{BCF}\left(\mathrm{ml} \mathrm{g}^{-1}\right)^{\mathrm{d}}$ & 328.25 \\
\hline MRT (day) ${ }^{\mathrm{e}}$ & 3.99 \\
\hline \multicolumn{2}{|l|}{ Shell of H. diversicolor supertexta } \\
\hline \multirow[t]{2}{*}{ Depuration rate constant, $k_{\mathrm{d}}\left(\mathrm{day}^{-1}\right)^{\mathrm{b}}$} & $0.044 \pm 0.044$ (with algae) \\
\hline & $0.063 \pm 0.022$ (without algae) \\
\hline Depuration half-life, $t_{1 / 2}$ (day) ${ }^{\mathrm{c}}$ & 15.75 \\
\hline Uptake rate constant, $k_{\mathrm{u}}\left(\mathrm{ml} \mathrm{g}^{-1} \text { day }^{-1}\right)^{\mathrm{a}}$ & $4.84 \pm 1.51$ \\
\hline $\mathrm{BCF}\left(\mathrm{ml} \mathrm{g}^{-1}\right)^{\mathrm{b}}$ & 48.36 \\
\hline \multicolumn{2}{|l|}{ G. tenuistipitata var. liui } \\
\hline Depuration rate constant, $k_{2 \mathrm{a}}\left(\mathrm{day}^{-1}\right)^{\mathrm{f}}$ & $0.811 \pm 0.21$ \\
\hline Uptake rate constant, $k_{1 \mathrm{a}}\left(\mathrm{ml} \mathrm{g}^{-1} \text { day }^{-1}\right)^{\mathrm{g}}$ & $211.62 \pm 47.09$ \\
\hline $\mathrm{BCF}_{\mathrm{a}}\left(\mathrm{ml} \mathrm{g}^{-1}\right)^{\mathrm{g}}$ & 261 \\
\hline $\operatorname{MRT}\left(\right.$ day) ${ }^{\mathrm{e}}$ & 3.75 \\
\hline \multicolumn{2}{|c|}{${ }^{a}$ Assimilation efficiency, uptake rate constant, and biomagnification factor (BMF) calculated from Eq. (1). } \\
\hline \multicolumn{2}{|c|}{${ }^{\mathrm{b}}$ Depuration rate constant calculated using the equation $\ln C=c+\left(k_{\mathrm{d}}+g\right) t$. } \\
\hline \multicolumn{2}{|c|}{${ }^{\mathrm{c}}$ Depuration half-life calculated from $t_{1 / 2}=\ln 2 / k_{\mathrm{d}}$. } \\
\hline \multicolumn{2}{|c|}{${ }^{\mathrm{d}}$ Bioconcentration factor $(\mathrm{BCF})$ calculated from Eq. (2). } \\
\hline \multicolumn{2}{|c|}{ e Mean residence time (MRT) calculated from Eq. (6). } \\
\hline \multicolumn{2}{|c|}{${ }^{\mathrm{f}}$ Depuration rate constant of algae calculated using the equation $\ln C=c+\left(k_{2 \mathrm{a}}+g_{\mathrm{a}}\right) t$. } \\
\hline
\end{tabular}

\subsection{Effect of parameters}

A typical example of the simulation carried out for the relative bioavailable $\mathrm{Zn}$ to $H$. diversicolor supertexta under various biokinetic and physiological conditions is shown in Fig. 4. In calculating the effect of each parameter for relative bioavailable $\mathrm{Zn}$ to abalone in Eq. (9), the mean numeric values of other parameters (Table 2) were used. Among the four parameters considered, relative bioavailable $\mathrm{Zn}$ to abalone is greatly affected by abalone depuration rate constant for $\mathrm{Zn}\left(k_{\mathrm{d}}\right)$ and abalone growth rate $(g)$ and is less dependent on algae growth rate $\left(g_{\mathrm{a}}\right)$ (Fig. 4$)$.

Fig. 4 reveals that the predicted relative bioavailable $\mathrm{Zn}$ to abalone varies by a difference change of $26-36 \%$ when $k_{\mathrm{d}}$ and $g$ increasing by one order of magnitude, as compared to a $0-7 \%$ difference change for $g_{\mathrm{a}}$ and $k_{2 \mathrm{a}}$. The result therefore suggests that $k_{\mathrm{d}}$ and $g$ should not be ignored in the AUC-based modeling, whereas $g$ also should not be ignored in the biokinetic modeling of $\mathrm{Zn}$ concentration in abalone. Our results thus further indicate that trophic transfer plays an important role in determining the relative bioavail- 


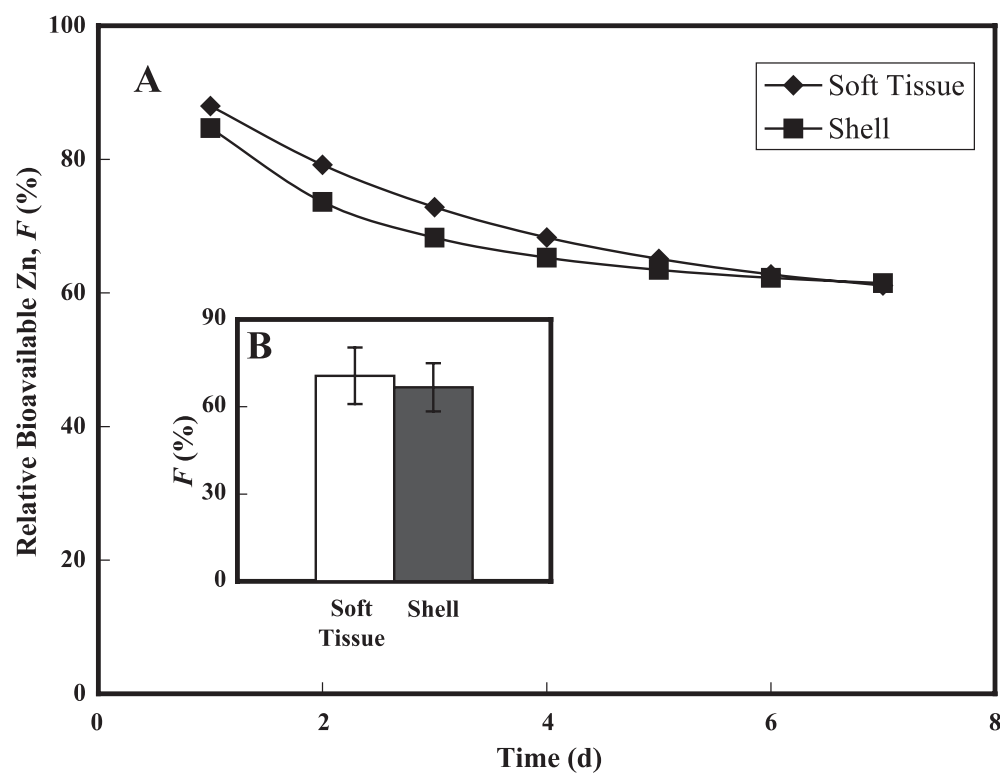

Fig. 3. Estimated relative bioavailable $\mathrm{Zn}$ to soft tissue and shell of $H$. diversicolor supertexta during uptake phase of exposure experiment: (A) Time profile of relative bioavailable $\mathrm{Zn}$ calculated by Eq. (9) and (B) average relative bioavailable $\mathrm{Zn}$ to soft tissue $(71.04 \pm 9.71 \%$ (mean \pm S.D. $))$ and to shell $(68.44 \pm 8.29 \%)$.

able $\mathrm{Zn}$ to abalone. Thus, it is possible to interpret relative bioavailable $\mathrm{Zn}$ to abalone in a mechanistic way based on certain important physiological and biokinetic parameters that can be obtained from deliberately laboratory measurements.

\subsection{Uncertainty analysis}

Because of limitations in data and theories to support proposed modeling, there is a need to characterize uncertainty and variability in the model approach and input parameters. In the current study, we explicitly address parameter uncertainty.

We applied a Monte Carlo approach to estimate the impact of parameter uncertainty on predictions of relative bioavailable $\mathrm{Zn}$ to abalone in Eq. (9). Lognormal distributions are used to represent abalone depuration rate of $\mathrm{Zn}\left(k_{\mathrm{d}}\right)$, algae depuration rate of $\mathrm{Zn}\left(k_{2 \mathrm{a}}\right)$, algae growth rate $\left(g_{\mathrm{a}}\right)$, and abalone growth rate $(g)$. To test the convergence and the stability of the numerical output, we performed independent runs at $1,4,5$, and 10 thousand iterations with each parameter sampled independently from the appropriate distribution at the start of each replicate. Largely because of limitations in the data used to derive model parameters, inputs were assumed to be independently. The result shows that 5000 iterations are sufficient to ensure the stability of results. In this case, the numerical error on the 95 th percentile is equal to $2 \%$. The simulation was implemented using @ RISK (Version 4.5, Professional Edition, Palisade, USA).

Fig. 5 illustrates the probability density functions (pdfs) and cumulative distribution functions (cdfs) of $\mathrm{Zn}$ bioavailavility in soft tissue and shell of abalone. Probabilistic 

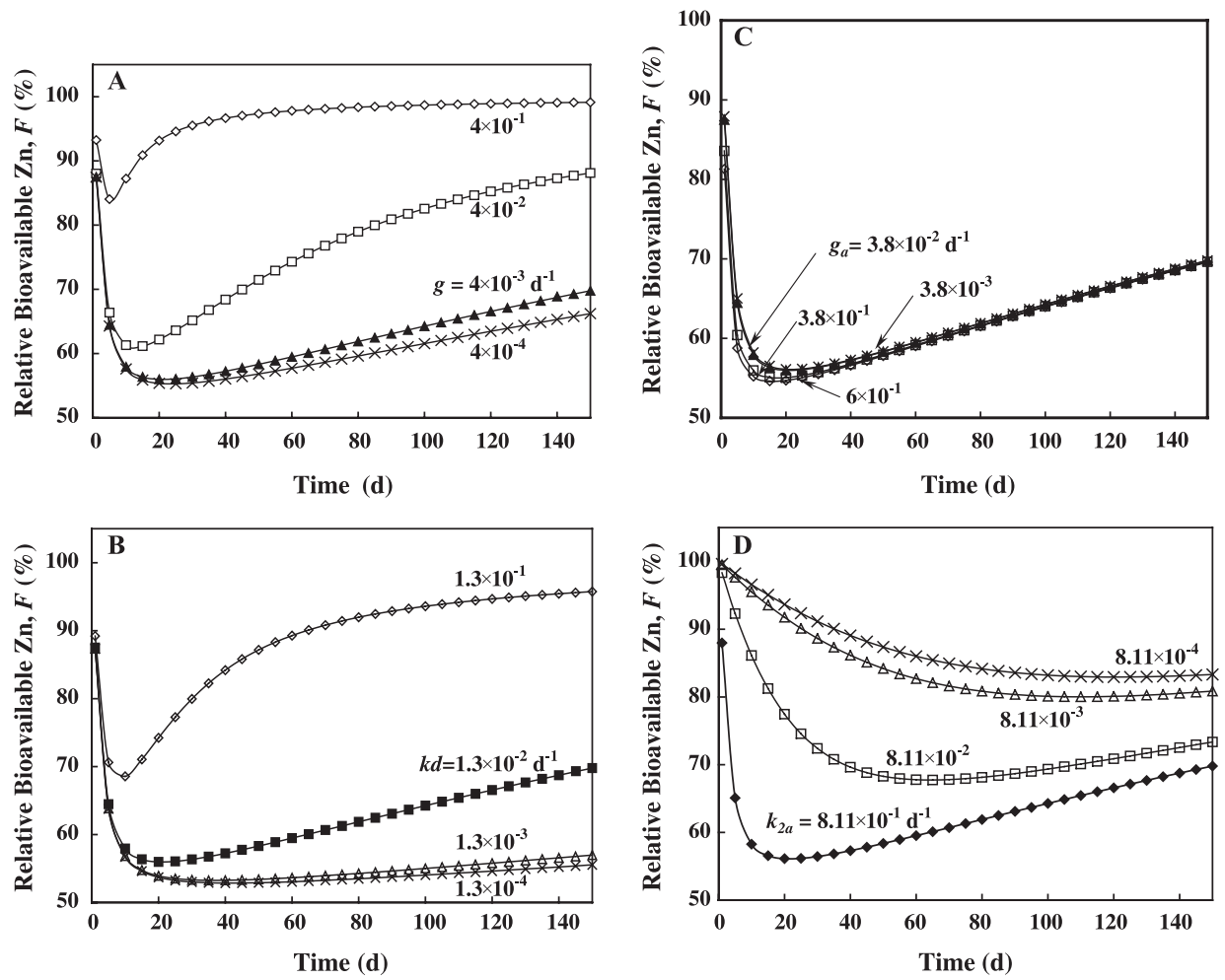

Fig. 4. Simulations carried out for relative bioavailable $\mathrm{Zn}$ to $H$. diversicolor supertexta under various biokinetic parameters ( $\mathrm{Zn}$ depuration rate constants for abalone $\left(k_{\mathrm{d}}\right)$ and for algae $\left(k_{2 \mathrm{a}}\right)$ ) and physiological parameters (growth rate constants for abalone $(g)$ and for algae $\left(g_{\mathrm{a}}\right)$ ). The solid symbols indicate mean numeric values shown in Table 2 and the open symbols represents increased and reduced order of magnitude of the parameter considered.

simulations of the AUC-based model produce skewed distributions of predicted relative bioavailable $\mathrm{Zn}$ to abalone. Percentile predictions of relative bioavailable $\mathrm{Zn}$ to abalone could be determined from cdfs illustrated in Fig. 5B and D. Fig. 6 shows box plots of interquartile- and 50th-percentile predictions associated with whisker plots indicating 10thand 90th-percentile predictions of relative bioavailable $\mathrm{Zn}$ to soft tissue and shell of abalone.

Fig. 5A and $\mathrm{C}$ shows that the pdfs of relative bioavailable $\mathrm{Zn}$ to $H$. diversicolor supertexta have a lognormal distribution of a geometric mean $(\mathrm{gm})$ of 0.55 and a geometric standard deviation (gsd) of $1.13(\mathrm{LN}(0.55,1.13))$ for soft tissue and a gm 0.63 with gsd 1.41 $(\mathrm{LN}(0.63,1.41))$ for shell, respectively. The relative bioavailable $\mathrm{Zn}$ to shell has a higher uncertainty as quantified by the variance, i.e., parameter variability of gsd. Fig. 5A and C also demonstrates that relative bioavailable $\mathrm{Zn}$ to soft tissue has a greater likelihood of occurrence than the same relative bioavailable $\mathrm{Zn}$ to shell in that the relative skewness and spread in modeled output associated with a long tail at higher bioavailable $\mathrm{Zn}$.

Compared with the field observations (Reinfelder et al., 1998), measured mean relative bioavailable $\mathrm{Zn}$ to bivalves $(F=55-65 \%)$ all fell within the 10th and 90th percentile 

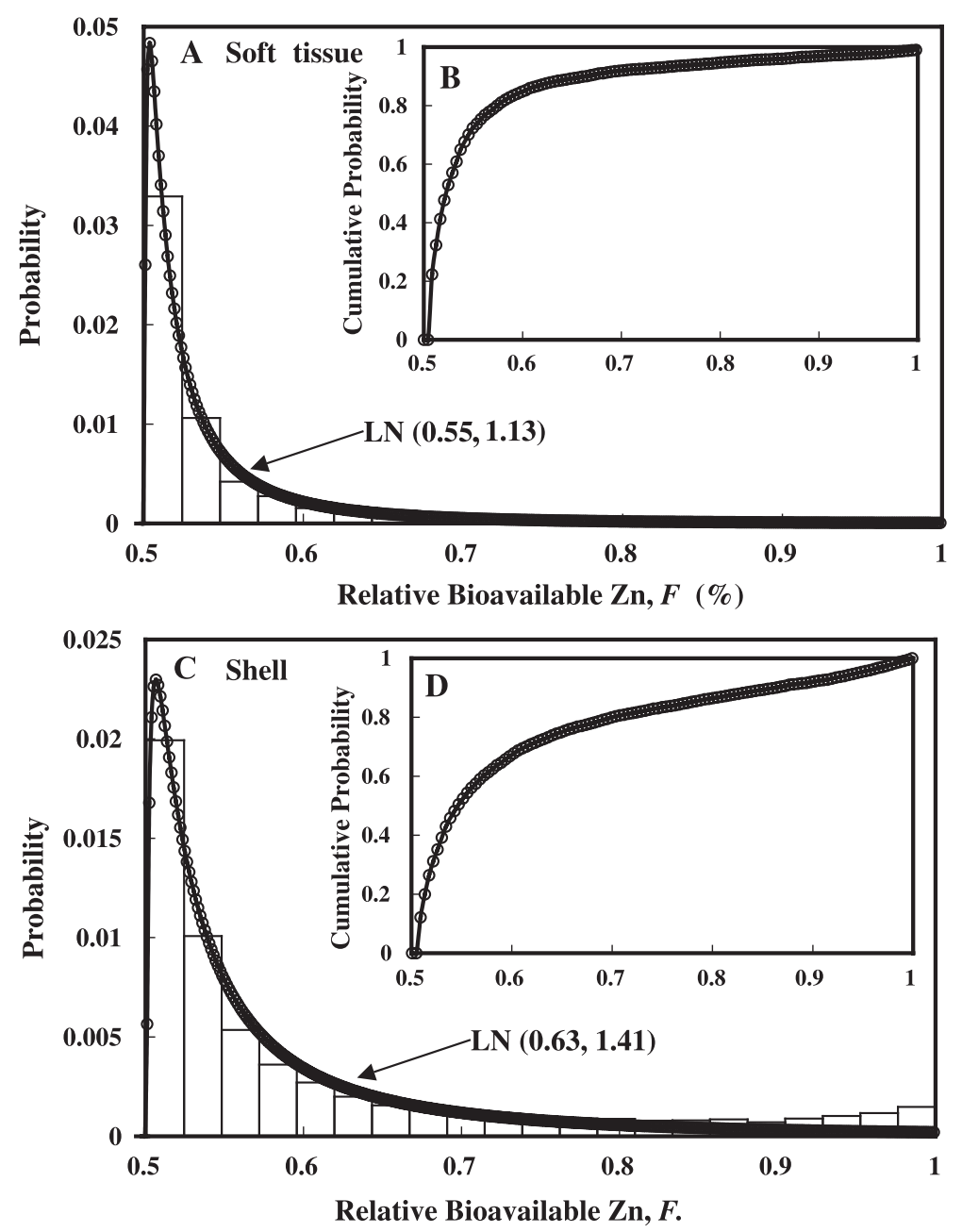

Fig. 5. Uncertainty simulations show probability density functions (pdfs) and cumulative distribution functions of relative bioavailable $\mathrm{Zn}$ to (A) soft tissue and (B) shell of H. diversicolor supertexta. Results indicate that pdfs of $\operatorname{LN}(0.55,1.13)$ and $\operatorname{LN}(0.63,1.41)$ for soft tissue and shell, respectively, in which $\operatorname{LN}(x, y)$ denotes lognormal distribution with geometric mean $x$ and geometric standard deviation $y$.

prediction range (Fig. 6). Relative to minimum and maximum field data, however, lower and upper probabilistic predictions were more conservative. This is evident that the modeling framework and the distributional parameters and assumptions in the model are appropriate for estimating relative bioavailable $\mathrm{Zn}$ to $H$. diversicolor supertexta.

\subsection{Implications}

Our study suggests that relative bioavailable $\mathrm{Zn}$ to $H$. diversicolor supertexta can be predicted with reasonable accepted ranges by a parsimonious AUC-based biokinetic 


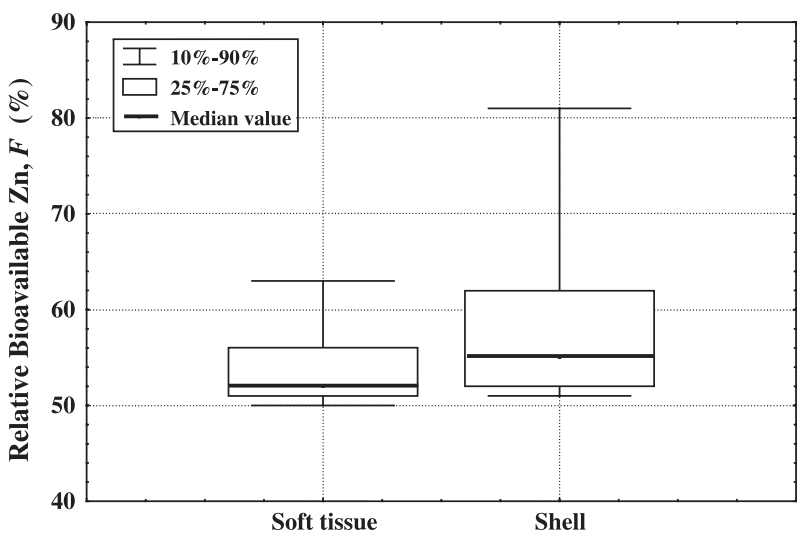

Fig. 6. Box and whisker plot representations of percentile predictions of relative bioavailable $\mathrm{Zn}$ to soft tissue and shell of $H$. diversicolor supertexta.

model if important metal-related biokinetic parameters (assimilation efficiency and depuration rate constant) and animal's physiological parameters (grazing rate and growth rate) are properly identified and determined. The AUC-based biokinetic model can also be used to assess the significance of trophic transfer and to understand the important biological processes governing relative bioavailable metals to aquatic animals.

Our results show that the depuration rate constant and growth rate constant of abalone and algae are critical in affecting relative bioavailable $\mathrm{Zn}$ to abalone. Consequently, variation of relative bioavailable $\mathrm{Zn}$ to abalone may reflect the influence of abalone growth rate, grazing rate, depuration rate, and assimilation efficiency, which are in turn dependent on food availability, season, and other environmental conditions. Wang et al. (1999) also pointed out that metal uptake may be more dependent on the physiological conditions of the aquatic animals than on the metal concentration in ingested food source, particularly for metals such as $\mathrm{Zn}$, which may be regulated in prey organisms.

The AUC-based biokinetic model may also be useful in ecological and human assessment when predicting the bioaccumulation of toxicants in aquacultural species from food, as it relates to consumption by humans or other species. As ecological risk assessment requirements demand more predictive power and accuracy, better methods are needed to accurately measure the concentration reaching internal target organs. The AUC concept derived from pharmacology in the proposed model in predicting relative bioavailable $\mathrm{Zn}$ to abalone meets this demand.

This present study revealed that metal-related biokinetics and physiological processes due to a stochastic environment are typically in rather complex ways within species and ecosystems. Such complex interactions present major challenges and require the proper experiments for exploring the underlying complex mechanisms. Thus, understanding the exposure pathways is critical for the setting of aquacultural water quality criteria. Our study highlights the significance of trophic transfer in the overall relative bioavailable metals to 
aquatic animals. Future work should focus on incorporating consumer-resource dynamics (Liao et al., 2002) and AUC-based biokinetics in a variety of circumstances to conduct more detailed mechanistic models in predicting more accurate metal bioavailability to aquacultural animals.

\section{Conclusions}

A mechanistic model based on an AUC-based biokinetic rate model can predict relative bioavailable $\mathrm{Zn}$ to abalone $H$. diversicolor supertexta. This present relative bioavailable metal prediction model indicates that growth rate constants and depuration rate constants of abalone and algae are the critical controlling parameters in predicting relative bioavailable $\mathrm{Zn}$ to abalone.

A sensitivity analysis of the model reveals that relative bioavailable $\mathrm{Zn}$ to abalone is greatly affected by growth rate and depuration rate constants of abalone and is less dependent on algae growth rate. An uncertainty analysis of the model shows that the probability density functions of relative bioavailable $\mathrm{Zn}$ to abalone followed a lognormal distribution of geometric means of 0.55 and 0.63 with geometric standard deviations of 1.13 and 1.41 for soft tissue and shell, respectively.

Before $H$. diversicolor supertexta can be designated as an appropriate biomonitor of $\mathrm{Zn}$ contamination in aquacultural and coastal waters, relative bioavailable metal information must be fully perceived. Our study suggests that relative bioavailable metals to aquatic animals can be predicted only when both physiological and biokinetic processes are considered.

\section{References}

Bourne, D.W.A., 1995. Mathematical Modeling of Pharmacokinetic Data. Technomic Publishing, Lancaster, PA, p. 64.

Chen, J.C., Lee, W.C., 1999. Growth of Taiwan abalone Haliotis diversicolor supertexta fed on Gracilaria tenuistipitata and artificial diet in a multiple-tier basket system. J. Shellfish Res. 18, 627-635.

de Vries, J., 1996. Toxicokinetics: quantitative aspects. In: Niesink, J.M., de Vries, J., Hollinger, M.A. (Eds.), Toxicology: Principles and Applications. CRC Press, Boca Raton, FL, USA, pp. 136-183.

Horsberg, T.E., Hoff, K.A., Nordmo, R., 1996. Pharmacokinetics of florfenicol and its metabolite florfenicol amine in Atlantic salmon. J. Aquat. Anim. Health 8, 292-301.

Lee, T.M., Chang, Y.C., Lin, Y.H., 1999. Differences in physiological responses between winter and summer Gracilaria tenuistipitata (Gigartinales, Rhodophyta) to varying temperatures. Bot. Bull. Acad. Sin. 40, 93-100.

Lee, B.G., Griscom, S.B., Lee, J.S., Choi, H.J., Koh, C.H., Luoma, S.N., 2000. Influences of dietary uptake and reactive sulfides on metal bioavailability from aquatic sediments. Science 287, 282-284.

Liao, C.M., Lin, M.C., Chen, J.S., Chen, J.W., 2002. Linking biokinetics and consumer-resource dynamics of zinc accumulation in pond abalone Haliotis diversicolor supertexta. Water Res. 36, 5102-5112.

Lin, M.C., Liao, C.M., 1999. ${ }^{65} \mathrm{Zn}(\mathrm{II})$ accumulation in the soft tissue and shell of abalone Haliotis diversicolor supertexta via alga Gracilaria tenuistipitata var. liui and the ambient water. Aquaculture 178, 89-101.

Martinsen, B., Horsberg, T.E., Varma, K.J., Sams, R., 1993a. Single dose pharmacokinetic study of florfenicol in Atlantic salmon (Salmo salar) in sea water at $11{ }^{\circ} \mathrm{C}$. Aquaculture $112,1-11$.

Martinsen, B., Sohlberg, S., Horsberg, T.E., Burke, M., 1993b. Single dose pharmacokinetic study of florfenicol in Atlantic salmon (Salmo salar) in sea water at $12{ }^{\circ} \mathrm{C}$. Aquaculture 118, 49-52. 
McCloskey, J.T., Schultz, I.R., Newman, M.C., 1998. Estimating the oral bioavailability of methylmercury to channel catfish (Ictalurus punctatus). Environ. Toxicol. Chem. 17, 1524-1529.

O’connell, M., Baldwin, D.S., Robertson, A.I., Rees, G., 2000. Release and bioavailability of dissolved organic matter from floodplain litter: influence of origin and oxygen levels. Freshw. Biol. 45, 333-342.

Pelkonen, O., Boobis, A.R., Gundert-Remy, U., 2001. In vitro prediction of gastrointestinal absorption and bioavailability: an experts' meeting report. Eur. J. Clin. Pharmacol. 57, 621-629.

Reinfelder, J.R., Fisher, N.S., 2001. The assimilation of elements ingested by marine copepods. Science 251, $794-796$.

Reinfelder, J.R., Fisher, N.S., Luoma, S.N., Nichols, J.W., Wang, W.X., 1998. Trace element trophic transfer in aquatic organisms: a critique of the kinetic model approach. Sci. Total Environ. 219, 117-135.

Roberts, S.M., Weimar, W.R., Vinson, J.R.T., Munson, J.W., Bergeron, R.J., 2002. Measurement of arsenic bioavailability in soil using a primate model. Toxicol. Sci. 67, 303-310.

Schroder, J.L., Basta, N.T., Si, J., 2003. In vitro gastrointestinal method to estimate relative bioavailable cadmium in contaminated soil. Environ. Sci. Technol. 37, 1365-1370.

van Straalen, N.M., 1996. Ecotoxicology. In: Niesink, R.J.M., de Vries, J., Hollinger, M.A. (Eds.), Toxicology: Principles and Applications. CRC Press, Boca Raton, FL, USA, pp. 1113-1139.

Wang, W.X., Fisher, N.S., 1997. Modeling metal bioavailability for marine mussels. Rev. Environ. Contam. Toxicol. 151, 39-65.

Wang, W.X., Qiu, J.W., Qian, P.Y., 1999. Significance of trophic transfer in predicting the high concentration of zinc in barnacles. Environ. Sci. Technol. 33, 2905-2909.

Yan, Q.L., Wang, W.X., 2002. Metal exposure and bioavailability to a marine deposit-feeding sipuncula, Sipunculus nudus. Environ. Sci. Technol. 36, 40-47.

Yang, H.S., Ting, Y.Y., 1986. Artificial propagation and culture of abalone (Haliotis diversicolor supertexta Lischke). Bull. Taiwan Fish. Res. Inst. 40, 195-201.

Yang, H.S., Ting, Y.Y., 1994. Studies on the availability of the abalone (Haliotis diversicolor supertexta Lischke) culture in southern Taiwan. Bull. Taiwan Fish. Res. Inst. 37, 145-154. 